\title{
PENGARUH PERPUTARAN MODAL KERJA DAN PERPUTARAN \\ AKTIVA TETAP TERHADAP PROFITABILITAS \\ (Pada Perusahaan Food and Beverages yang Terdaftar di \\ Bursa Efek Indonesia Pada Tahun 2009-2015)
}

\author{
Dhea Zatira \\ Program Studi S1 Manajemen, Fakultas Ekonomi dan Bisnis \\ Universitas Muhammadiyah Tangerang
}

\begin{abstract}
ABSTRAK
Penelitian ini bertujuan untuk menguji secara empiris pengaruh perputaran modal kerja dan perputaran aktiva tetap terhadap profitabilitas pada perusahaan Food and Beverages yang terdaftar di Bursa Efek Indonesia.

Penelitian ini menggunakan sampel perusahaan Food and Beverages yang terdaftar di Bursa Efek Indonesia selama periode 2009 - 2015. Berdasarkan metode purposive sampling, jumlah perusahaan Food and Beverages yang dijadikan sample dalam penelitian ini sebanyak 8 perusahaan. Pengujian hipotesis menggunakan analisis regresi data panel dengan menggunakan program EViews 9.0 .

Hasil penelitian menunjukan bahwa perputaran modal kerja tidak memiliki pengaruh terhadap profitabilitas. Sedangkan perputaran aktiva tetap berpengaruh positif terhadap profitabilitas.

Kata kunci: Perputaran Modal Kerja, Perputaran Aktiva Tetap dan Profitabilitas

\section{PENDAHULUAN}

Tujuan investasi adalah untuk

Return on assets adalah kemampuan mendapatkan laba yang optimal, yaitu laba yang bisa meningkatkan nilai perusahaan serta memenuhi tingkat kepuasan investor. Laba atau profitabilitas adalah kemampuan perusahaan memperoleh laba dalam hubungannya dengan penjualan, total aktiva maupun modal sendiri (Sartono, 2010:122). Rasio profitabilitas terbagi menjadi beberapa rasio yaitu, margin laba (profit margin), return on investment (ROI) atau sering disebut juga dengan return on assets (ROA), return on equity (ROE), dan laba per lembar saham (Kasmir, 2012:199).

perusahaan untuk menghasilkan laba selama periode tertentu (Toto Prihadi, 2010:138). Untuk mencapai laba yang diinginkan, maka perusahaan harus menjalankan aktifitasnya, sedangkan untuk menjalankan aktifitas perusahaan memerlukan dana yang akan dijadikan sebagai modal kerja (seperti kas, piutang dan persediaan yang terdapat pada aktiva lancar) dan aktiva tetap (seperti gedung, mesin tanah dan lainnya).

Modal kerja merupakan modal yang digunakan untuk melakukan kegiatan operasi perusahaan. Modal kerja diartikan sebagai investasi yang ditanamkan dalam aktiva
\end{abstract}


lancar atau aktiva jangka pendek seperti kas, bank, surat berharga, piutang, persediaan dan aktiva lancar (Kasmir 2012:250). Menurut Harjito dan Martono (2011:75) dikemukakan bahwa perhatian utama dalam manajemen modal kerja adalah pada manajemen aktiva lancar (gross working capital) perusahaan, yaitu kas, sekuritas, piutang, persediaan serta pendanaan (terutama kewajiban lancar atau jangka pendek) yang diperlukan untuk mendukung aktiva lancar. Penentu besar kecilnya modal kerja menurut Bambang Riyanto (2012:64) ada dua yaitu: periode perputaran atau periode terkaitnya modal kerja dan pengeluaran kas setiap harinya.

Selain menginvestasikan dana pada modal kerja, perusahaan juga harus berinvestasi pada aktiva tetap untuk mendukung oprasional perusahaan. Aktiva tetap ialah aktiva yang tahan lama yang tidak atau secara berangsur-angsur habis turut serta dalam proses produksi dan ditinjau dari lama perputaran aktiva tetap ialah aktiva yang mengalami proses perputaran dalam jangka waktu panjang (Bambang Riyanto, 2011:115) Menurut Satria dan Tugi (2008) Pada umumnya nilai ekonomis suatu aktiva tetap akan mengalami penurunan yang disebabkan pemakaian, kerusakan dan ketinggalan zaman karena faktor ekonomis dan factor teknis, maka aktiva ini memerlukan suatu pengelolaan dan kebijakan khusus baik dalam penggunaa, pemeliharaan, penguasaan maupun pencatan akuntansi dan mempunyai peranan penting dalam aktivitas produksinya.

Oleh karena pentingnya aktiva tetap bagi perusahaan, maka perlu di perhitungkan besarnya biaya yang akan dikeluarkan aktiva tetap yang disebut penyusutan (depresiasi). Semakin tinggi biaya depresiasi yang dikeluarkan perusahaan, maka laba yang diterima semakin rendah, sebaliknya semakin rendah depresiasi perusahaan maka laba yang diterima akan semakin tinggi.

Manajer keuangan harus bisa merencanakan dengan baik besarnya jumlah modal kerja dan aktiva tetap yang tepat dan sesuai dengan kebutuhan perusahaan, karena jika terjadi kelebihan atau kekurangan pada investasi tersebut akan mempengaruhi tingkat profitabilitas yang akan diterima. Investasi yang ditanamkan pada modal kerja diharapkan dapat kembali ke perusahaan melalui hasil penjualan. Semakin cepat perputaran modal kerja dan perputaran aktiva tetap dinilai akan semakin baik, karena akan semakin besar pula return yang akan di hasilkan Perusahaan

Penelitian ini bertujuan untuk mengetahui signifikansi pengaruh perputaran variabel-variabel bebas yang terdiri 
perputaran modal kerja (working capital turnover) dan perputaran aktiva tetap (fixed assets turnover) terhadap variabel terikat yaitu profitabilitas yang diproksikan pada return on assets. Berdasarkan pada konsep, kajian-kajian teori yang relevan serta hasil penelitian sebelumnya, maka hipotesis dapat dirumuskan sebagai berikut:

H1 : Perputaran modal kerja (working capital turnover) secara parsial berpengaruh positif terhadap profitabilitas.

H2 : Perputaran aktiva tetap (fixed assets turnover) secara parsial berpengaruh positif terhadap profitabilitas.

H3 : Perputaran modal kerja (working capital turnover) dan perputaran aktiva tetap (fixed assets turnover) secara simultan berpengaruh positif terhadap profitabilitas.

\section{METODOLOGI PENELITIAN}

Penelitian ini dilakukan untuk memperoleh informasi mengenai bagaimana pengaruh perputaran modal kerja (working capital turnover) dan perputaran aktiva tetap (fixed assets turnover) terhadap return on assets (ROA) pada perusahaan sektor Food and Beverages yang terdaftar di Bursa Efek Indonesia periode tahun 2009-2015. Sampel yang digunakan dalam penelitian ini adalah Purposive Sampling, yaitu tipe pemilihan sampel berdasarkan pertimbanganpertimbangan tertentu dan pertimbangan yang diambil itu berdasarkan tujuan penelitian. Dari hasil pemilihan sample dengan menggunakan Purposive Sampling terpilih 8 perusahaan yang memenuhi kriteria dari total populasi sebanyak 14 perusahaan.

Metode penelitian yang digunakan adalah asosiatif kausal analitis. Asosiatif analitis menurut Sugiyono (2011:11-12) merupakan penelitiana yang bertujuan untuk mengetahui hubungan antara dua variabel atau lebih, metode ini dapat dibangun suatu teori yang berfungsi untuk menjelaskan, meramalkan dan mengontrol suatu gejala. Sedangkan asosiatif kausal analitis artinya hubungan sebab akibat dimana variabel $X$ akan memperngaruhi variabel Y.

Jenis data yang digunakan adalah data kuantitatif, data kuantitatif adalah data berupa angka-angka. Kemudian dianalisis lebih lanjut untuk kemudian diambil kesimpulan. Sumber data dalam penelitian ini adalah laporan-laporan keuangan suatu perusahaan yang berbentuk neraca dan laba rugi yang diperoleh dari Indonesian Capital Market Directory (ICMD), idx.co.id serta web perusahaan yang bersangkutan. 
Variabel bebas dalam penelitian ini adalah perputaran modal kerja (X1) dan perputaran aktiva tetap (X2) terhadap return on assets (Y), sehingga dapat disajikan oprasional variabelnya sebagai berikut:

\begin{tabular}{|c|c|c|c|}
\hline No. & $\begin{array}{l}\text { Jenis } \\
\text { Varia-bel }\end{array}$ & $\begin{array}{l}\text { Cara Menghi- } \\
\text { tung }\end{array}$ & Rumus \\
\hline 1. & $\begin{array}{l}\text { Modal } \\
\text { Kerja } \\
\text { (working } \\
\text { capital } \\
\text { turnover) }\end{array}$ & $\begin{array}{l}\text { Menunjukkan } \\
\text { hubungan antara } \\
\text { modal kerja } \\
\text { dengan penjualan } \\
\text { yang dapat } \\
\text { diperoleh } \\
\text { perusahaan untuk } \\
\text { tiap rupiah modal } \\
\text { kerja }\end{array}$ & $\begin{array}{l}\text { WCTO = } \\
\text { Penjualan } \\
\begin{array}{l}\text { Modal kerja } \\
\text { rata - rata }\end{array}\end{array}$ \\
\hline 2. & $\begin{array}{l}\text { Perputaran } \\
\text { Aktiva } \\
\text { Tetap } \\
\text { (fixed } \\
\text { assets } \\
\text { turnover) }\end{array}$ & $\begin{array}{l}\text { Digunakan untuk } \\
\text { mengukur berapa } \\
\text { kali dana yang } \\
\text { ditanamkan } \\
\text { dalam asset tetap } \\
\text { berputar dalam } \\
\text { satu periode }\end{array}$ & $\begin{array}{c}\text { FATO = } \\
\text { Penjualan } \\
\begin{array}{c}\text { Total aktiva } \\
\text { tetap }\end{array} \\
\text { Kasmir, } \\
\text { 2012: } 184\end{array}$ \\
\hline 3. & $\begin{array}{l}\text { Profitabi- } \\
\text { litas } \\
\text { (Return on } \\
\text { assets) }\end{array}$ & $\begin{array}{l}\text { Mengukur } \\
\text { kemampuan } \\
\text { perusahaan } \\
\text { dalam } \\
\text { mendayagunakan } \\
\text { asset untuk } \\
\text { memperoleh laba }\end{array}$ & $\begin{array}{c}\text { ROA }= \\
\text { Laba Bersih } \\
\begin{array}{c}\text { Rata - rata } \\
\text { total aset }\end{array} \\
\text { Toto Prihadi, } \\
2011: 154\end{array}$ \\
\hline
\end{tabular}

\section{Analisis Regresi Data Panel}

Analis statitik dimulai dari pengujian model regresi data panel balance dimana unit cross-sectional memiliki jumlah observasi time series yang sama. Dalam membuat regresi data panel, kita dapat menggunakan tiga pendekatan yaitu:

\section{1) Common Effect (Pooling Least Square),} Dalam menganalisis regresi dengan data panel dapat menggunakan analisis model ordinary least square atau Common effect. Pendekatan ini adalah yang paling sederhana untuk mengestimasi data panel. Pendekatan ini hanya menggabungkan cross section dan data time series tanpa melihat perbedaan antar waktu dan individu. Kemudian digunakan metode ordinary least square untuk mengestimasi model data panel (Istiani dalam Arry,2017).

\section{2) Fixed Effect}

Menurut (Winarno,2015:9.15) Fixed Effect adalah bahwa suatu objek memiliki konstanta yang tetap besarannya untuk berbagai periode waktu. Demikian juga dengan koefisien regresinya, tetap besarannya dari waktu ke waktu (time invariant).

\section{3) Random Effect}

Random Effect Model digunakan untuk mengatasi kelemahan metode efek tetap yang menggunakan variabel semu, sehingga model mengalami ketidakpastian. Tanpa menggunakan variabel semu, metode efek random mengunakan residual, yang di duga memiliki hubungan antar waktu atau antar objek (Winarno, 2015:9.17).

\section{Pemilihan Model Regresi Data Panel} Analisis rergresi data panel dilakukan untuk menentukan model yang tepat untuk digunakan dengan melakukan pengujian sebagai berikut: 


\section{1) Uji Chow}

Uji Chow (F statistik) adalah pengujian yang dilakukan untuk mengetahui apakah model yang digunakan adalah common effect atau fixed effect. (Bambang Juanda dan Junaidi, dalam Rochayati, 2015. Pengujian ini dilakukan dengan hipotesis sebagai berikut:

H0 : Model menggunakan pendekatan common effect

H1 : Model menggunakan pendekatan Fixed Effect

Pengujian ini mengikuti distribusi $\mathrm{F}$ statistik, dimana jika F statistic lebih besar dari F tabel maka H0 ditolak. Nilai Chow menunjukkan nilai $\mathrm{F}$ statistik dimana bila nilai Chow yang kita dapat lebih besar dari nilai $\mathrm{F}$ tabel yang digunakan berarti kita menggunakan model fixed effect atau kita dapat melihat kepada nilai probabilitas cross section F dan Chi Square, dengan ketentuan:

1. Jika probabilitas $<0,05$, berarti $\mathrm{H} 0$ ditolak, dan menggunakan $\mathrm{H} 1$.

2. Jika Probabilitas > 0,05, berarti $\mathrm{H} 0$ diterima.

\section{2) Uji Haussman.}

Uji Haussman digunakan untuk menentukan apakah menggunakan model fixed effect atau model random effect yang paling tepat, maka uji haussman dilakukan dengan hipotesis berikut:

Ho = Random Effect Model

H1 = Fixed Effect Model

Statistik Uji Haussman ini mengikuti distribusi statistic Chi Square dengan degree of freedom sebanyak $\mathrm{k}$, dimana $\mathrm{k}$ adalah jumlah variabel independen. Jika nilai statistik Haussman lebih besar dari nilai kritisnya maka H0 ditolak dan model yang tepat adalah model fixed effect, sedangkan sebaliknya bila nilai statistik haussman lebih kecil dari nilai kritisnya maka model yang tepat adalah model random effect. Atau dapat melihat kepada nilai probabilitas cross section random, dengan ketentuan sebagai berikut:

1) Jika probabilitas $<0,05$, maka tolak $\mathrm{H} 0$, dan terima $\mathrm{H} 1$

2) Jika Probabilitas $>0,05$, maka terima $\mathrm{HO}$

\section{3) Uji Langrage Multiplier}

Uji Langrage Multiplier (LM) digunakan untuk mengetahui model mana yang lebih baik, apakah lebih baik diestimasi dengan menggunakan model common effect atau model random effect. Hipotesis yang digunakan dalam uji LM adalah sebagai berikut:

Ho = Model mengikuti common effect

H1 = Model mengikutil random effect 


\section{Pegujian Hipotesis}

a. Uji Hipotesis secara bersama-sama (Uji-F)

Uji $\mathrm{F}$ dimaksudkan untuk menguji apakah semua variabel bebas yang terdapat dalam model mempunyai pengaruh secara bersama-sama terhadap variabel terikat. Adapun kriteria pengambilan keputusan sebagai berikut:

Jika probabilitas $<0,05$, maka Ha diterima

Jika probabilitas >0,05, maka Ha ditolak

\section{b. Koefisien Determinasi}

Koefisien Determinasi (R2) untuk melihat seberapa baik garis regresi menjelaskan datanya (goodnessof fit), artinya bagaimana garis regresi yang dibentuk sesuai dengan data. Jika semua data terletak pada regresi atau dengan kata lain semua nilai residual adalah nol maka kita mempunyai garis regresi yang sempurna (Agus Widarjono, 2013: 24) dalam Gusniati, 2012. Pengujian koefisien determinasi (R2) bertujuan untuk mengukur seberapa jauh kemampuan model dalam menerangkan variasi variabel dependen. Besarnya nilai koefisien determinasi adalah antara nol sampai dengan satu. Jika nilai koefisien determinasi suatu model mendekati satu berarti variabel-variabel independen dapat memberikan hampir semua informasi yang dibutuhkan untukmenerangkan variasi pada variabel dependen (Arry, 2017)

\section{c. Uji Hipotesis Secara Parsial (Uji t)}

Uji hipotesis ini dilakukan untuk mengetahui ada/atau tidaknya pengaruh variabel bebas dengan variabel terikatnya secara parsial. Pengujian secara simultan ini dilakukan dengan cara membandingkan antara tingkat signifikansi $\mathrm{t}$ dari hasil pengujian dengan nilai signifikansi yang digunakan dalam penelitian ini. Cara pengujian parsial terhadap variabel independen yang digunakan dalam penelitian ini adalah sebagai berikut:

Jika probabilitas $<0,05$, maka Ha diterima

Jika probabilitas > 0,05, maka Ha ditolak

\section{HASIL PENELITIAN DAN \\ PEMBAHASAN}

\section{Analisis Statistik Deskriptif}

$\begin{array}{llll} & \text { ROA } & \text { WCTO } & \text { FATO } \\ \text { Mean } & 0.104286 & 6.612143 & 2.796429 \\ \text { Median } & 0.100000 & 3.960000 & 2.040000 \\ \text { Maximum } & 0.340000 & 44.25000 & 14.74000 \\ \text { Minimum } & 0.020000 & -1.120000 & 0.480000 \\ \text { Std. Dev. } & 0.069749 & 8.041036 & 2.362550 \\ \text { Observations } & 56 & 56 & 56\end{array}$

Sumber: Data diolah dengan Eviews 9, 2017

Rata-rata perputaran modal kerja (working capital turnover) selama periode pengamatan 2009 sampai dengan 2015 adalah 6.612143. Nilai perputaran modal 
kerja (working capital turnover) tertinggi yaitu sebesar 44.25000 dan nilai perputaran modal kerja (working capital turnover) terendah yaitu -1.120000. Dimana nilai standar deviasi dari variabel nilai perputaran modal kerja (working capital turnover) adalah sebesar 8.041036

Rata-rata perputaran aktiva tetap (fixed assets turnover) selama periode pengamatan 2009 sampai dengan 2015 adalah 2.796429. Nilai perputaran aktiva tetap (fixed assets turnover) tertinggi yaitu sebesar 14.74000 dan nilai perputaran aktiva tetap (fixed assets turnover) terendah yaitu 0.480000. Dimana nilai standar deviasi dari variabel nilai perputaran aktiva tetap (fixed assets turnover) adalah sebesar 2.362550

\section{Uji Berpasangan Dua Model}

a. Uji Chow (Common Effect vs Fixed Effect)

Redundant Fixed Effects Tests

Equation: EQ02

Test Cross-section fixed effects

\begin{tabular}{llll}
\hline \hline Effects Test & Statistic & d.f. & Prob. \\
\hline \hline Cross-section $\mathrm{F}$ & 6.353173 & $(7,46)$ & 0.0000 \\
Cross-section Chi-square & 37.878474 & 7 & 0.0000 \\
\hline \hline
\end{tabular}

Sumber: Data diolah dengan Eviews 9, 2017

Dengan menggunakan dasar

keputusan Uji Chow, diketahui berdasarkan tabel distribusi $\mathrm{F}$ pada $\mathrm{df}=(7,46)$ dengan $\alpha=$ $5 \%$ diperoleh nilai f-tabel sebesar 2,22. Maka dapat disimpulkan f-hitung (6.353173) > ftabel $(2,22)$, yang artinya gagal menerima
H0. Sedangkan nilai probabilitas Crosssection $\mathrm{F}$ dan Chi-square $0.000<\alpha(0,05)$. Maka model regresi linear berganda data panel dalam Uji Chow yang terbaik adalah menggunakan model regresi data panel dengan metode fixed Effect

\section{b. Uji Hausman (Fixed Effect vs Random Effect)}

Correlated Random Effects - Hausman Test

Equation: EQ02

Test Cross-section random effects

\begin{tabular}{llll}
\hline \hline Test Summary & $\begin{array}{l}\text { Chi-Sq. } \\
\text { Statistic }\end{array}$ & Chi-Sq. d.f. & Prob. \\
\hline \hline Cross-section random & 0.347762 & 2 & 0.8404 \\
\hline \hline
\end{tabular}

Sumber: Data diolah dengan Eviews 9, 2017

Dengan menggunakan dasar keputusan seperti diatas, diketahui berdasarkan tabel distribusi Chi-square pada $\mathrm{df}=(2)$ dengan $\alpha=5 \%$ diperoleh nilai t-tabel sebesar 6,00. Maka dapat disimpulkan Chisquare hitung $(0.347762)<$ Chi-square tabel $(6,00)$, yang artinya menerima H0. Maka model regresi linear berganda dalam Uji Haussman data panel yang terbaik adalah menggunakan model regresi data panel dengan metode Random Effect. 


\section{c. Uji Langrage Multiplier (Common Effect vs Random Effect)}

Lagrange Multiplier Tests for Random Effects

Null hypotheses: No effects

Alternative hypotheses: Two-sided (Breusch-Pagan) and onesided

(all others) alternatives

\begin{tabular}{llll}
\hline \hline \multicolumn{3}{l}{ Test Hypothesis } & \\
& Cross-section & Time & \multicolumn{2}{l}{ Both } \\
\hline \hline Breusch-Pagan & $\begin{array}{c}26.42754 \\
(0.0000)\end{array}$ & $\begin{array}{r}1.829251 \\
(0.1762)\end{array}$ & $\begin{array}{c}28.25679 \\
(0.0000)\end{array}$ \\
\hline \hline
\end{tabular}

Sumber: Data diolah dengan Eviews 9, 2017

Berdasarkan hasil diatas nilai probabilitas Cross-section Breausch-pagan < $\alpha(0,05)$, maka dapat disimpulkan bahwa Random Effect Model (REM) lebih layak digunakan dibandingkan Common Effect Model (CEM)

\section{Kesimpulan Model}

Kesimpulan Model Regresi Dan Data Panel

\begin{tabular}{|l|l|l|l|}
\hline No. & Metode & Pengujian & Hasil \\
\hline 1 & Uji Chou & CEM vs FEM & FEM \\
\hline 2 & Uji Hausman & REM vs FEM & REM \\
\hline 3 & $\begin{array}{l}\text { Uji Lagrange } \\
\text { Multiplier }\end{array}$ & CEM vs REM & REM \\
\hline
\end{tabular}

Berdasarkan pengujian terhadap ketiga model regresi data panel, dapat disimpulkan bahwa model Random effect dalam regresi data panel digunakan lebih lanjut dalam mengestimasi pengaruh perputaran modal kerja (working capital turnover) dan aktiva tetap (fixed assets turnover) terhadap profitabilitas (return on asets) perusahaan Food and Beverages tahun 2009 - 2015.

\section{Uji Hipotesis}

a. Uji F

\begin{tabular}{ll}
\hline \hline F-statistic & 3.891786 \\
Prob (F-statistic) & 0.026484 \\
\hline \hline
\end{tabular}

Sumber: Data diolah dengan Eviews 9, 2017

Pada output diatas menunjukkan bahwa nilai F-statistic sebesar 3.891786. Sementara f-tabel dengan tingkat $\alpha=5 \%$, df1 $(\mathrm{k}-1)=2, \mathrm{df} 2(\mathrm{n}-\mathrm{k})=53$ didapat nilai $\mathrm{F}$ table sebesar 3,17. Dengan demikian F statistic 3.891786 > F table 3,17 dan nilai probabilitas F statistic $0,002740<0,05$, maka Ho ditolak dan Ha diterima. Sehingga dapat disimpulkan bahwa terdapat pengaruh secara bersama-sama fixed assets turn over dan working capital turn over terhadap return on asets perusahaan Food and Beverage tahun 2009-2015.

\section{b. Koefisien Determinasi}

\begin{tabular}{ll}
\hline \hline R-squared & 0.128054 \\
Adjusted R-squared & 0.095150 \\
\hline \hline
\end{tabular}

Sumber: Data diolah dengan Eviews 9, 2017

Pada table diatas menunjukkan bahwa nilai $\mathrm{R}$ square sebesar 0.128054 , artinya bahwa variasi perubahan naik turunnya return on assets dapat dijelaskan oleh fixed assets turn over dan working capital turn over sbesar 12,8\%, sementara sisanya $87,2 \%$ dijelaskan oleh variable- 
variabel lain yang tidak diteliti dalam penelitian ini.

\begin{tabular}{lllll}
\multicolumn{1}{c}{$\mathbf{U j i} \mathbf{~ t}$} & & & & \\
\hline \hline Variable & Coefficient & Std. Error & t-Statistic & Prob. \\
\hline \hline C & 0.081526 & 0.015360 & 5.307704 & 0.0000 \\
WCTO & -0.000976 & 0.001217 & -0.802463 & 0.4264 \\
FATO & 0.010447 & 0.003914 & 2.669417 & 0.0105 \\
\hline \hline
\end{tabular}

Sumber: Data diolah dengan Eviews 9, 2017

Nilai t-statistic WCTO -0.802463 , sementara t table dengan tingkat $\alpha=5 \%$, df $(\mathrm{n}-\mathrm{k})=53$ didapat nilai $\mathrm{t}$ table sebesar 2,00. Dengan demikian t-statistic $(-0.802463)<\mathrm{t}$ table $(2,00)$ dan nilai probabilitas $0.4264>$ 0,05, maka Ho diterima, sehingga dapat disimpulkan bahwa perputaran modal kerja (working capital turnover) tidak berpengaruh terhadap return on assets. Hasil penelitian ini mendukung penelitian Hoiriya dan Lestariningsih (2015) dan penelitian Chaidir dan Lintang (2015) yang menyatakan modal kerja mempunyai pengaruh yang tidak signifikan terhadap tingkat profitabilitas perusahaan. Namun berbanding terbalik dengan penelitianyang dilakukan Rahma (2011) yang menyatakan bahwa working capital turnover berpengaruh positif terhadap profitabilitas.

Nilai t-statistic FATO 2.669417, sementara $\mathrm{t}$ table dengan tingkat $\alpha=5 \%$, df $(\mathrm{n}-\mathrm{k})=53$ didapat nilai $\mathrm{t}$ table sebesar 2,00. Dengan demikian t statistic (2.669417) > t- table $(2,00)$ dan nilai probabilitas $0.0105<$ 0,05, maka Ha diterima, sehingga dapat disimpulkan bahwa perputaran aktiva tetap (fixed assets turnover) berpengaruh positf terhadap return on assets. Hasil penelitian ini mendukung penelitian Wika dan Kadek (2015) yang menyatakan Investasi aktiva tetap berbanding lurus dengan profitabilitas Namun berbanding terbalik dengan penelitian yang dilakukan Andriani dan Arifati (2016) yang menyatakan bahwa Perputaran aktiva tetap secara parsial berpengaruh negatif tidak signifikan terhadap profitabilitas

\section{KESIMPULAN DAN SARAN 1. Kesimpulan}

Berdasarkan hasil pengujian yang telah dilakukan, dapat disimpulkan beberapa hal, yaitu:

a. Variabel perputaran modal kerja (working capital turnover) tidak berpengaruh terhadap return on assets pada perusahaan subsektor Food and Beverages yang terdaftar di Bursa Efek Indonesia tahun 2009 sampai dengan 2015. Hal ini di buktikan dengan $p$-value uji t lebih dari alfa 5 persen yaitu 0.4264 . Dengan hasil tersebut maka perputaran modal kerja (working capital turnover) 
tidak berpengaruh terhadap return on assets

b. Variabel perputaran aktiva tetap (fixed assets turnover) berpengaruh terhadap return on assets pada perusahaan subsektor Food and Beverages yang terdaftar di Bursa Efek Indonesia tahun 2009 sampai dengan 2015. Hal ini di buktikan dengan $p$-value uji t kurang dari alfa 5 persen yaitu 0.0105 . Dengan hasil tersebut maka perputaran aktiva tetap (fixed assets turnover) berpengaruh terhadap return on assets.

c. Secara simultan (bersama-sama) menunjukan bahwa terdapat pengaruh antara modal kerja (working capital turnover) dan aktiva tetap (fixed assets turnover) terhadap return on assets pada perusahaan subsektor Food and Beverages yang terdaftar di Bursa Efek Indonesia tahun 2009 sampai dengan 2015. Hal ini di buktikan dengan $F$ statistic kurang dari alfa 5 persen yaitu 0.026484 . besarnya pengaruh secara simultan bisa dilihat dari R-squared sebesar 0.128054. Dengan hasil tersebut maka dapat disimpulkan bahwa modal kerja (working capital turnover) dan perputaran aktiva tetap (fixed assets turnover) secara bersama-sama berpengaruh terhadap return on assets.

\section{Saran}

a. Untuk penelitian selanjutnya, sebaiknya peneliti menambah variabel penelitain, objek penelitian, dan tahun yang ditelitipun. Karena dengan penambahan variabel, objek dan tahun, maka hasil penelitian akan lebih signifikan.

b. Bagi pihak manajemen perusahaan agar mampu menganalisis dan menentukan besarnya nilai modal kerja (working capital turnover) dan aktiva tetap (fixed assets turnover) dengan baik.

c. Bagi para investor, hasil penelitian ini dapat memberikan informasi kepada investor dan calon investor mengenai kondisi keuangan suatu perusahaan terutama dari segi keuntungan yang diperoleh dari dana yang diinvestasikan pada aktiva lancar maupun aktiva tetap perusahaan.

\section{DAFTAR PUSTAKA}

Andari, Arifati dan Andini. 2016. Pengaruh Perputaran Barang Jadi, Arus Kas, Piutang, dan Aktiva Tetap Terhadap Profitabilitas Pada Perusahaan Perdagangan Eceran Yang Terdaftar di BEI Periode 2009-2014

Chaidir dan Lintang, Kawuryan Shanti. 2015. Pengaruh Manajemen Modal Kerja Terhadap Rentabilitas Perusahaan Pada PT Sepatu Bata. 
Chakiki, Noer dan Djawoto. 2016. Pengaruh Perputaran Piutang dan Perputaran Modal Kerja Terhadap Likuiditas Perusahaan Consumer Goods.

Eksandy, Arry. 2017. Pengaruh Ukuran Perushaan, Solvabilitas, Profitabilitas Dan Komite Audit Terhadap Audit Delay (Pada Perusahaan Properti dan Real Estate yang Terdaftar di Bursa Efek Indonesia pada Tahun 20122015)

Hoiriya dan Lestariningsih, Marsudi. 2015. Pengaruh Perputaran Modal Kerja, Perputaran Piutang, Perputaran Persediaan Terhadap Profitabilitas Perusahaan Manufaktur

Indonesian Capital Market Directory (ICMD)

Kasmir. 2012. Analisis Laporan Keuangan. Jakarta: PT. Raja Grafindo Persada.

Martono dan Harjito, Agus. 2011. Manajemen Keuangan, Edisi Kedua, Cetakan Ketiga, Yogyakarta: Ekonisia.

Satria dan Gugup Tugi P. 2008. Aktiva Tetap Terhadap Laba Perusahaan Suatu Kasus Pada PT. Yasunli Abadi Utama Plastik Factory III Cibitung. Prospek, Vol 1, No.1. Januari.

Rahma Aulia, 2011. Analisis Pengaruh Manajemen Modal Kerja terhadap Profitabilitas Perusahaan (Studi Pada Perusahaan Manufaktur PMA dan PMDN yang Terdaftar di BEI Periode 2004-2008)

Prihadi, Toto. 2010. Analisis Laporan Keuangan. Jakarta: Ppm Manajemen.
Riyanto, Bambang. 2012. Dasar-dasar Pembelajaran Perusahaan. Yogyakarta: BPFE.

Rochayati, Yati. 2015. Pengaruh Pembiayaan Mudharabah, Musyarakah Dan Murabahah Terhadap Laba Bersih Pada Bank Syariah. Tangerang.

Sugiyono. 2011. Metode Penelitian Kuantitatif Kualitatif dan $R \& D$. Bandung: Alfabeta.

Sartono, Agus. 2010. Manajemen Keuangan. Yogyakarta: BPFE.

Widarjono, Agus. 2013. Ekonometrika: Pengantar dan aplikasinya, Ekonosia, Jakarta.

Winarno, Wing Wahyu. 2015. Analisis Ekonometrika dan Statistika dengan EViews. Yogyakarta: UPP STIM YKPN.

Wika, Kadek dan Ayu. 2015 Pengaruh Investasi Aktiva Tetap, Likuiditas, Solvabilitas, dan Modal Kerja Terhadap Profitabilitas Perusahaan Otomotif Dan Komponen Yang Terdaftar di Bursa Efek Indonesia Tahun 2010-2013

www.idx.co.id. 